Open Access

\title{
Erratum to: A cluster randomized trial of a multifaceted quality improvement intervention in Brazilian intensive care units: study protocol
}

The CHECKLIST-ICU Investigators and the BRICNet ${ }^{*}$

\section{Erratum}

Due to an error during the production process Alexandre Cavalcanti was incorrectly added to the author list of the original article [1]. The author list has now been updated in the original published article from:

Alexandre Cavalcanti and The CHECKLIST-ICU Investigators and the BRICNet

To:

The CHECKLIST-ICU Investigators and the BRICNet

BioMed Central apologises to the authors and readers for this error and any inconvenience this has caused.

Received: 25 June 2015 Accepted: 1 July 2015

Published online: 13 August 2015

\section{References}

1. The CHECKLIST-ICU Investigators and the BRICNet. A cluster randomized trial of a multifaceted quality improvement intervention in Brazilian intensive care units: study protocol. Implement Sci. 2015;10:8.

* Correspondence: abiasi@hcor.com.br

${ }^{1}$ Research Institute - Hospital do Coração (IEP- HCor), Rua Abílio Soares 250, 12th floor, SP, CEP: 04005-000, São Paulo, Brazil
Submit your next manuscript to BioMed Central and take full advantage of:

- Convenient online submission

- Thorough peer review

- No space constraints or color figure charges

- Immediate publication on acceptance

- Inclusion in PubMed, CAS, Scopus and Google Scholar

- Research which is freely available for redistribution

Submit your manuscript at www.biomedcentral.com/submit
() Biomed Central 